\title{
Determining Impacts on Non-Performing Loan Ratio in Romania
}

\author{
Adriana Daniela CIUREL ${ }^{1}$ \\ Tiberiu STOICA ${ }^{2}$
}

\begin{abstract}
This paper aims to investigate some of the determinants of non-performing loans in the Romanian banking sector by means of Vector Error Correction (VEC). The increase in non-performing loans is the most relevant factor that financial institutions face in order to maintain an adequate level of solvency in the context of current economic decline. The objectives of the study presented in this document are to estimate and understand the historical relationships between various macroeconomic factors and the evolution of non-performing loans, in order to facilitate the prediction of future non-performing loans based on macroeconomic forecasts.

The conclusions obtained should be taken as guidelines and be the starting point for a reflection that helps to define next steps in the methodological development of planning models as well as in other aspects detailed in the diversification sections and credit management policies. This paper presents in the first place an executive summary of the main conclusions of the study, as well as a reference to the origin of the data used and the methodology applied. In the development of the model, we use public data from the National Bank of Romania, World Bank and the National Institute of
\end{abstract}

Keywords: cointegration, VEC, non-performing loans, interest rate, credit risk.

JEL classification: $C 58, E 40, E 44, G 21$.

DOI: $10.24818 / \mathrm{RMCI} .2019 .2 .155$

\section{Literature Review}

There are several studies published in this field which investigate the factors that induce non-performing loans by examining potential links between bank-specific variables and macroeconomic factors.

For the predictions of non-performing loans, the error correction model of Engle and Granger (1987) is used. Basically, Engle and Granger's approach consists of two steps:

1. Model a long-term equilibrium relationship -called cointegrationbetween the dependent variable - the variable to be predicted - and a set of explanatory variables. This is done by a regression of the explanatory variables on the dependent variable. The residuals of said regression are the estimation of the cointegration relation.

${ }^{1}$ Adriana Daniela Ciurel, Bucharest Academy of Economic Studies, E-mail: adriana_ daniela_ciurel@yahoo.com

2 Tiberiu Stoica, Bucharest Academy of Economic Studies, E-mail: tiberiusstoica @yahoo.com

155 Review of International Comparative Management $\quad$ Volume 20, Issue 2, May 2019 
2. Use this equilibrium relation, delays of the dependent variable and other variables that capture its short-term behavior to predict the future values of the dependent variable.

The idea underlying this approach is that if there is a long-term equilibrium relationship between two or more variables, any deviation from this equilibrium is necessarily temporary, and the variables will tend to return to their equilibrium relationship. This will improve the prediction of the variables regarding a model that only takes into account their short-term behavior.

Many models have been created for forecasting future developments in financial markets. Demirgüç-Kunt and Detragiache (2005) used multivariate models for forecasting a continuous variable, which comprise either one equation or a system of equations, like in VAR and VECM models.

Rinaldi and Sanchis-Arellano (2006) found that lower indebtedness and higher house prices are associated with a lower ratio of non-performing loans, using aggregate or country-level data to estimate panel VECM models to study the dynamics of non-performing loans.

M. Nkusu in 2011 used data for a small panel of countries in a VAR model with few variables and found that lower unemployment and higher GDP growth are associated with a decrease in non-performing loans on the short term.

Sofoklis D. Vogiazas and Eftychia Nikolaidou (2011) investigated the determinants of non-performing loans in the Romanian banking system, and found that macroeconomic variables, the inflation, the unemployment rate, and the country's external debt to GDP influence the credit risk.

According Louzis et al. (2011) and N. Klein (2013) studies, the quality of loans can be explained mainly by macroeconomic variables. They have studied data from Central, Eastern and Southern European countries, to understand the non-performing loans behaviors in their own researches, by using both macroeconomic and bank-specific factors.

N. Yoshino et al. (2015) develop a model that can capture both macro shocks and idiosyncratic shocks to financial institutions in a vector error correction setting. They found that the response of non-performing loans to macro shocks and idiosyncratic innovations shows that using a model with macro variables only is insufficient, because under favorable economic conditions some banks show negative performance or vice versa.

Karsten Staehr and Lenno Uusküla (2017) found that macroeconomic and macro-financial variables have important roles in predicting future developments in non-performing loans. They have analyzed the influence of GDP growth, the inflation and unemployment rate, the current account balance and real house prices on non-performing loans in their paper Forecasting models for non-performing loans in the EU countries. 


\section{Methodology}

The literature on non-performing loans is limited and largely consists of studies produced after a global financial crisis, and focuses on explaining the dynamics of non-performing loans, not on forecasting future developments.

This paper uses macroeconomic time series data to estimate projection or forecasting models with potentially long forecasting horizons.

In the first place, the behavior of the aggregates is analyzed together with the variables that may have an influence on them, especially the statistical characteristics. For this, it was verified if they are stationary, if they present some seasonal behavior and if there are causalities between them both contemporary and temporal precedence, in order to build better models.

The models can be estimated using various econometric techniques. In this case we chose the methodology from general to particular and by the VEC models (Vector Error Correction). As our main objective is to obtain the best possible forecast, the prediction error was fundamental in the selection of models.

\section{Data}

The data come from various data sources, such as National Bank of Romania, World Bank and the National Institute of Statistics, starting from December 2009, to November 2017. We used monthly data. The detailed description of the variables is presented bellow:

Non-performing loans ratio based on EBA s definition (\%) - NPR

Source: NBR's monthly bulletin

Nominal EUR/RON - EURRON

Source: NBR website

Natural logarithm of average gross revenue - WAGE

Source: National Institute of Statistics

Monetary policy interest rate (\%) - $\mathrm{R}$

Source: National Bank of Romania website

Software used: E-views

\section{Model}

Error-Correction Model (ECM) the general case

$x_{t}=\left(x_{1 t}, x_{2 t}, \ldots, x_{n t}\right)$

$\Delta x_{t}=\pi_{0}+\pi x_{t-1}+\pi_{1} \Delta x_{t-1}+\pi_{2} \Delta x_{t-2}+\ldots+\pi_{p} \Delta x_{t-p}+\varepsilon_{t}$

$\pi_{0}=$ an $(n \times 1)$ vector of intercept terms with elements $\pi_{i 0}$ 
$\pi_{i}=(n \times n)$ coefficient matrices with elements $\pi_{j k}(i)$

$\pi=$ a matrix with elements $\pi_{j k}$ such that one or more of the $\pi_{j k} \neq 0$

$\varepsilon_{t}=$ an $(n \times 1)$ vector with elements $\varepsilon_{i t}$

Characteristic roots, rank and Johansen cointegration test

$\Delta x_{t}=\pi x_{t-1}+\sum_{i=1}^{p-1} \pi_{i} \Delta x_{t-i}+\varepsilon_{t}$

$\pi=-\left(I-\sum_{i=1}^{p} A_{i}\right)$ and $\pi_{i}=-\sum_{j=i+1}^{p} A_{j}$

$\operatorname{rank}(\pi)$ - number of cointegrating vectors

rank of a matrix - number of its characteristics roots that differ from zero.

$\lambda_{i}$ - characteristic root

$\lambda_{\text {trace }}(r)=-T \sum_{i=r+1}^{n} \ln \left(1-\hat{\lambda}_{i}\right)$

$\lambda_{\text {max }}(r, r+1)=-T \ln \left(1-\hat{\lambda}_{r+1}\right)$

$\hat{\lambda}_{i}=$ the estimated values of the characteristic roots (also called eigenvalues)

obtained from the estimated $\pi$ matrix.

$T=$ the number of usable observations

We test the impact of macroeconomic variables on non-performing loans ratio. Different variables were tested but we decided to keep only the ones mentioned above as we consider they are the most eloquent indicators to test how the macroeconomic evolutions impact credit risk in a financial institution. Most of the research papers use those variables. Vector Error Correction (VEC) Model was used in the current analysis, being a popular tool in risk management and macroeconomics. The goal is to obtain the Impulse Response Functions (IRFs). The graphs (IRFs) indicate how a shock on R, WAGE and EURRON impact NPR indicator. We selected 2 lags in our VEC model as we considered that financial and labor markets evolution impact immediatelly non-performing loans ratio.

ADF tests indicate that all variables are non-stationary. The variables become stationary after applying the first difference (I(1) variables). This may indicate that the variables are cointegrated (there is linear combination between them that is stationary). We preferred to use Johansen test for cointegration as it is a more direct way to test this assumption as compared to the two-step EngleGranger approach. Johansen test also indicates the number of cointegrated relations, information which is not provided by Engle-Granger approach. Johansen test indicates one cointegrating relation. Therefore it is indicated to use VEC model in the analysis.

We also performed Granger causality test to see which of the three variables can be used in forecasting NPR evolution. According to the test all three 
variables (R, WAGE and EURRON) can predict NPR. So VEC model can be adapted to provide NPR projections.

\section{Results}

The implemented VEC model provided the following IRFs:

Response to Cholesky One S.D. Innovations

Response of NPR to R

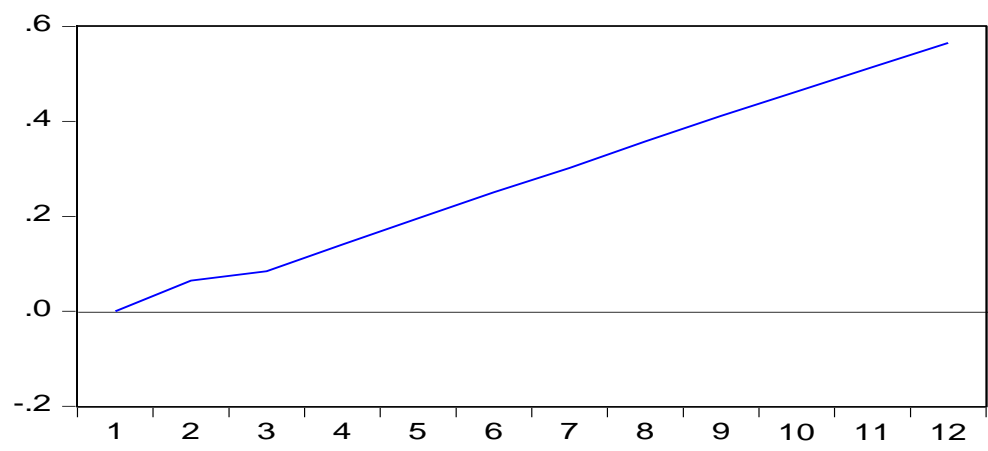

Response of NPR to WAGE

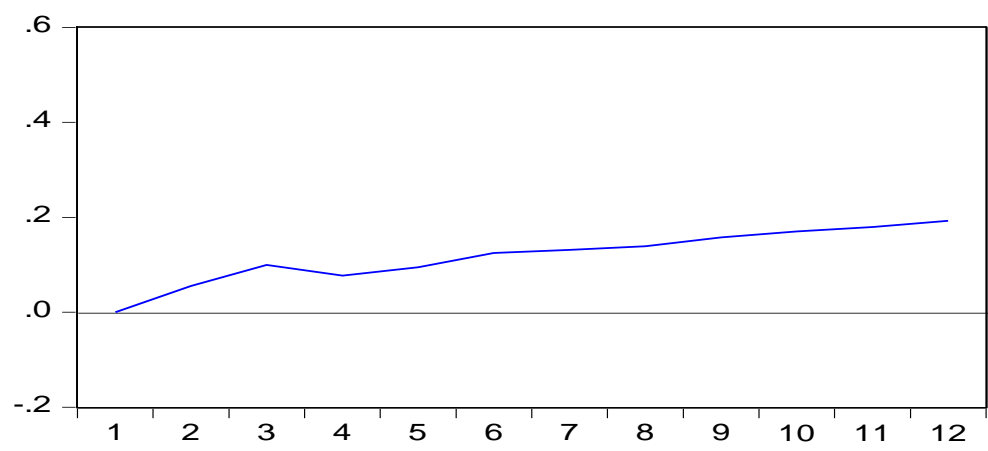

Response of NPR to EURRON

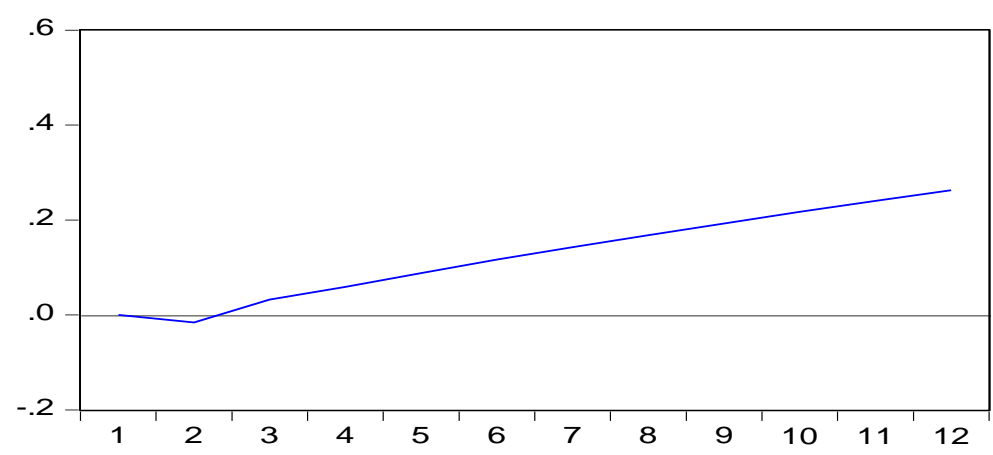

Source: Our calculations 


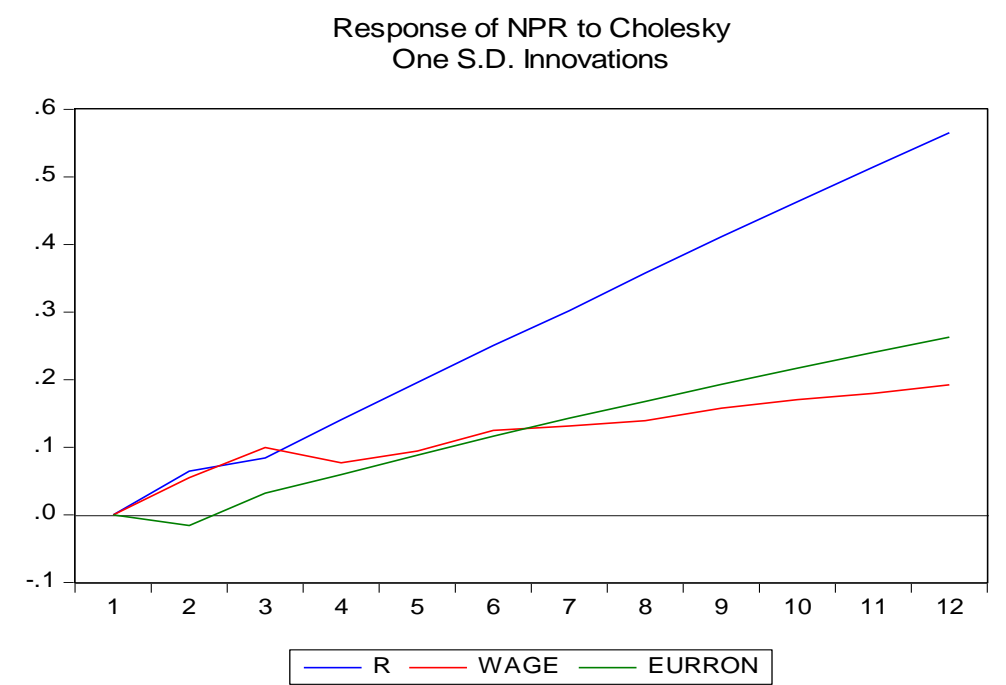

Source: Our calculations

IRFs description

Shocks on R, WAGE and EURRON

Response: NPR

Ox 12 months time

Oy Response to Cholesky to one standard innovations

\section{Chart 1}

Indicates the response of NPR to a monetary policy interest rate shock. According to the monetary theory a shock on interest rates influence significantly NPR. For example an increase of the monetary policy interest rate generates a surge in NPR as individuals and companies will face higher costs with their current loans.

Our results indicate a persistent effect of an interest rate shock on NPR, which is in line with the monetary theory. A shock on $\mathrm{R}$ variable generates an increase of NPR in the first one and a half month. NPR's rate of increase drops in the next following two months and then recovering to its initial value in the remaining 8 months. The slower NPR increase between month 1.5 and 3.5 could be explained by the commercial banks policy to restructure a share of the total loans. Chart 1 shows that the effect of the restructuring policy is dissipated after 3.5 months.

\section{Chart 2}

Indicates the response of NPR to WAGE shock.

Macroeconomics theory indicates that a decrease of average revenue in the economy generates the increase of NPR, as individuals will have lower financial resources to cover their debt. Our results, show that NPR posts a upward trend in the first 2.5 months but then the rate of increase drops. This could be explained by the fact that a share of individuals have also other financial resources like rents, 
remittances from abroad, small businesses, savings or resources from black and grey economy. Our conclusion is that an interest rate shock has a more powerful influence on NPR as compared to average wage.

Chart 3

Indicates the respone of NPR to EURRON shock.

The depreciation of the national currency usually generates the increase of NPR. Our results indicate that NPR tends to increase significanlty after an FX shock. However in the first 1.5 month, NPR drops slightly which is against economic theory. This result could be explained by the following factor: individuals tend to pay a higher amount in first 1 or 2 months after a period of RON depreciation as they expect the FX to continue its upward trend in the future. This indicates a prudent approach.

\section{Conclusions}

We started the analysis of this study with the selection of three macroeconomic variables (i.e. nominal EUR/RON, natural logarithm of average gross revenue, and monetary policy interest rate). The main aim of our study was to investigate the determinants of NPLs by using the Romanian banking data.

A VEC model was implemented to test the impact of these macroeconomic variables on non-performing loans ratio in Romania. We found that there is a longrun connection between monetary policy interest rate, the average gross revenue, EUR/RON and non-performing loans ratio. According to IRFs, NPR is influenced by R, WAGE and EURRON evolution, which is in line with macroeconomic theory. However the impact of variables on NPR is asymmetric, as R and EURRON have a more powerful impact on NPR evolution as compared to WAGE variable. In conclusion financial market shocks influence to a higher extent nonperforming loans evolution as compared to labor market shocks. Our finding is that commercial banks should monitor both financial markets and labor market evolution but more emphasis should be put on financial indicators impact on NPR.

This study used data from Romania only, therefore our findings may not be applicable for other countries. Therefore future studies can use data from other developed or developing countries. Also in the current study we have used only three macroeconomic variables to investigate their impact on NPLs ratio, but future studies can use other macroeconomic variables, such as inflation rate, unemployment rate, real estate prices, exports and imports, consumer price index, GDP ratio, and so on, to investigate the NPLs behavior. The results of these studies will be beneficial for the commercial banks, because it can help to anticipate the effects of each variable on the NPLs level, and can be also very helpful in predicting and controlling future banking crisis.

\section{References}

Anastasiou, D.; Louri, H.; Tsionas, E. G. (2016), "Non-performing loans in the euro area: are core-periphery banking markets fragmented?" Bank of Greece Working Paper, 219; 
Demirgüç-Kunt, A.; Detragiache, E. (2005), "Cross-country empirical studies of systemic bank distress: a survey", National Institute Economic Review, 192(1): 68-83;

Espinoza, R. and Prasad A., (2010), "Nonperforming Loans in the GCC Banking System and their Macroeconomic Effects", IMF. Working Paper 10/224.

Ghosh, A. (2015), "Banking-industry specific and regional economic determinants of non-performing loans: evidence from US states." Journal of Financial Stability, 20, 93-104.

Kjosevski, J.; Petkovski, M. (2016), "Non-performing loans in the Baltic states: determinants and macroeconomic effects", Baltic Journal of Economics, 17(2): 25-44.

Klein N., (2013), "Non-performing loans in CESEE: Determinants and impact on macroeconomic performance", IMF Working Paper, 13/72, Washington.

Louzis, D. P., Vouldis, A. T.; Metaxas, V. L. (2012), "Macroeconomic and bankspecific determinants of non-performing loans in Greece: A comparative study of mortgage, business and consumer loan portfolios." Journal of Banking \& Finance, 36(4): 1012-1027.

Makri, V.; Tsagkanos, A.; Bellas, A. (2014), "Determinants of non-performing loans: the case of Eurozone." Panoeconomicus, 61(2): 193-206.

Messai, A. S.; Jouini, F. (2013), "Micro and macro determinants of nonperforming loans." International Journal of Economics and Financial Issues, 3(4): 852-860.

Naoyuki Yoshino, Farhad Taghizadeh-Hesary and Farhad Nili, (2015), "Estimating Dual Deposit Insurance Premium Rates and Forecasting Non-performing Loans: Two New Models", Asian Development Bank Institute Working Paper Series, No. 510, January 2015.

Nkusu, M. (2011), "Non-performing loans and macrofinancial vulnerabilities in advanced economies." IMF Working Papers, WP/11/161.

Skarica, B. (2014), "Determinants of non-performing loans in Central and Eastern European countries." Financial Theory and Practice, 38(1): 37-59.

Staehr Karsten and Uusküla Lenno, (2017), "Forecasting models for nonperforming loans in the EU countries", Working Paper Series 9/2017.

Vatansever Metin and Hepşen Ali, (2013), "Determining Impacts on NonPerforming Loan Ratio in Turkey", Journal of Finance and Investment Analysis, vol. 2, no.4, 2013, 119-129 ISSN: 2241-0998 (print version), 2241-0996(online) Scienpress Ltd.

Vogiazas Sofoklis D. and Nikolaidou Eftychia, (2011), "Investigating the Determinants of Non-performing Loans in the Romanian Banking System: An Empirical Study with Reference to the Greek Crisis", Hindawi Publishing Corporation Economics Research International, Volume 2011. 


\section{APPENDIX}

Null Hypothesis: EURRON has a unit root

Exogenous: Constant

Lag Length: 0 (Automatic - based on SIC, maxlag=11)

\begin{tabular}{lccc}
\hline \hline & t-Statistic & Prob.* \\
\hline \hline Augmented Dickey-Fuller test statistic & -1.253746 & 0.6482 \\
\hline Test critical values: & 1\% level & -3.500669 & \\
& $5 \%$ level & -2.892200 & \\
& $10 \%$ level & -2.583192 & \\
\hline \hline
\end{tabular}

*MacKinnon (1996) one-sided p-values.

Augmented Dickey-Fuller Test Equation

Dependent Variable: D(EURRON)

Method: Least Squares

Date: 01/30/18 Time: 21:48

Sample (adjusted): 2010M01 2017M11

Included observations: 95 after adjustments

\begin{tabular}{lrlrr}
\hline \hline \multicolumn{1}{c}{ Variable } & Coefficient & Std. Error & t-Statistic & Prob. \\
\hline \hline \multicolumn{1}{c}{ EURRON(-1) } & -0.038834 & 0.030975 & -1.253746 & 0.2131 \\
\multicolumn{1}{c}{ C } & 0.175237 & 0.136412 & 1.284619 & 0.2021 \\
\hline \hline R-squared & 0.016621 & Mean dependent var & 0.004280 \\
Adjusted R-squared & 0.006047 & S.D. dependent var & 0.037760 \\
S.E. of regression & 0.037646 & Akaike info criterion & -3.700371 \\
Sum squared resid & 0.131799 & Schwarz criterion & -3.646605 \\
Log likelihood & 177.7676 & Hannan-Quinn criter. & -3.678646 \\
F-statistic & 1.571880 & Durbin-Watson stat & 1.705556 \\
Prob(F-statistic) & 0.213077 & & \\
\hline \hline
\end{tabular}

Conclusion

Eurron is I (1) variable.

It becomes stationary after applying the first difference.

163 Review of International Comparative Management $\quad$ Volume 20, Issue 2, May 2019 
Null Hypothesis: NPR has a unit root

Exogenous: Constant

Lag Length: 6 (Automatic - based on SIC, maxlag=11)

\begin{tabular}{lccc}
\hline \hline & & t-Statistic & Prob.* $^{*}$ \\
\hline \hline \multicolumn{2}{l}{ Tugmented Dickey-Fuller test statistic } & -1.354832 & 0.6008 \\
\hline Test critical values: & 1\% level & -3.505595 & \\
& 5\% level & -2.894332 & \\
& $10 \%$ level & -2.584325 & \\
\hline \hline
\end{tabular}

*MacKinnon (1996) one-sided p-values.

Augmented Dickey-Fuller Test Equation

Dependent Variable: D(NPR)

Method: Least Squares

Date: 01/30/18 Time: 21:50

Sample (adjusted): 2010M07 2017M11

Included observations: 89 after adjustments

\begin{tabular}{crcrr}
\hline \hline Variable & Coefficient & Std. Error & t-Statistic & Prob. \\
\hline \hline NPR(-1) & -0.014800 & 0.010924 & -1.354832 & 0.1792 \\
D(NPR(-1)) & 0.031925 & 0.098679 & 0.323530 & 0.7471 \\
D(NPR(-2)) & 0.134336 & 0.098552 & 1.363106 & 0.1766 \\
D(NPR(-3)) & 0.096461 & 0.099217 & 0.972231 & 0.3338 \\
D(NPR(-4)) & 0.079063 & 0.099405 & 0.795362 & 0.4287 \\
D(NPR(-5)) & 0.056343 & 0.098832 & 0.570082 & 0.5702 \\
D(NPR(-6)) & 0.455644 & 0.099275 & 4.589699 & 0.0000 \\
C & 0.196711 & 0.176495 & 1.114545 & 0.2683 \\
\hline \hline R-squared & 0.373423 & Mean dependent var & -0.032472 \\
Adjusted R-squared & 0.319275 & S.D. dependent var & 0.538118 \\
S.E. of regression & 0.443980 & Akaike info criterion & 1.299515 \\
Sum squared resid & 15.96660 & Schwarz criterion & 1.523213 \\
Log likelihood & -49.82841 & Hannan-Quinn criter. & 1.389681 \\
F-statistic & 6.896274 & Durbin-Watson stat & 2.091898 \\
Prob(F-statistic) & 0.000002 & & \\
\hline \hline
\end{tabular}

Conclusion

NPR is I(1) variable.

It becomes stationary after applying the first difference. 
Null Hypothesis: R has a unit root

Exogenous: Constant

Lag Length: 3 (Automatic - based on SIC, maxlag=11)

\begin{tabular}{lccc}
\hline \hline & t-Statistic & Prob.* $^{*}$ \\
\hline \hline \multicolumn{2}{l}{ Augmented Dickey-Fuller test statistic } & -0.327204 & 0.9157 \\
\hline Test critical values: & 1\% level & -3.503049 & \\
& 5\% level & -2.893230 & \\
& $10 \%$ level & -2.583740 & \\
\hline \hline
\end{tabular}

*MacKinnon (1996) one-sided p-values.

Augmented Dickey-Fuller Test Equation

Dependent Variable: $\mathrm{D}(\mathrm{R})$

Method: Least Squares

Date: 01/30/18 Time: 21:51

Sample (adjusted): 2010M04 2017M11

Included observations: 92 after adjustments

\begin{tabular}{lrlrr}
\hline \hline \multicolumn{1}{c}{ Variable } & Coefficient & Std. Error & t-Statistic & Prob. \\
\hline \hline $\mathrm{R}(-1)$ & -0.001894 & 0.005787 & -0.327204 & 0.7443 \\
$\mathrm{D}(\mathrm{R}(-1))$ & 0.102583 & 0.099661 & 1.029319 & 0.3062 \\
$\mathrm{D}(\mathrm{R}(-2))$ & 0.082555 & 0.096377 & 0.856580 & 0.3940 \\
$\mathrm{D}(\mathrm{R}(-3))$ & 0.229219 & 0.091109 & 2.515861 & 0.0137 \\
$\mathrm{C}$ & -0.017630 & 0.025078 & -0.702995 & 0.4839 \\
\hline \hline R-squared & 0.161520 & Mean dependent var & -0.051630 \\
Adjusted R-squared & 0.122970 & S.D. dependent var & 0.108296 \\
S.E. of regression & 0.101419 & Akaike info criterion & -1.686290 \\
Sum squared resid & 0.894872 & Schwarz criterion & -1.549237 \\
Log likelihood & 82.56936 & Hannan-Quinn criter. & -1.630974 \\
F-statistic & 4.189806 & Durbin-Watson stat & 1.674451 \\
Prob(F-statistic) & 0.003771 & & \\
\hline \hline
\end{tabular}

Conclusion

$r$ is I(1) variable.

It becomes stationary after applying the first difference. 
Null Hypothesis: WAGE has a unit root

Exogenous: Constant

Lag Length: 11 (Automatic - based on SIC, maxlag=11)

\begin{tabular}{lccc}
\hline \hline & t-Statistic & Prob.* \\
\hline \hline Augmented Dickey-Fuller test statistic & 8.230784 & 1.0000 \\
\hline Test critical values: & 1\% level & -3.510259 & \\
& 5\% level & -2.896346 & \\
& $10 \%$ level & -2.585396 & \\
\hline \hline
\end{tabular}

*MacKinnon (1996) one-sided p-values.

Augmented Dickey-Fuller Test Equation

Dependent Variable: D(WAGE)

Method: Least Squares

Date: 01/30/18 Time: 21:52

Sample (adjusted): 2010M12 2017M11

Included observations: 84 after adjustments

\begin{tabular}{crcrr}
\hline \hline Variable & Coefficient & Std. Error & t-Statistic & Prob. \\
\hline \hline WAGE(-1) & 0.148748 & 0.018072 & 8.230784 & 0.0000 \\
D(WAGE(-1)) & -0.952116 & 0.080348 & -11.84996 & 0.0000 \\
D(WAGE(-2)) & -0.939450 & 0.084805 & -11.07776 & 0.0000 \\
D(WAGE(-3)) & -0.824566 & 0.101962 & -8.087005 & 0.0000 \\
D(WAGE(-4)) & -0.738287 & 0.102391 & -7.210504 & 0.0000 \\
D(WAGE(-5)) & -0.687343 & 0.098080 & -7.007969 & 0.0000 \\
D(WAGE(-6)) & -0.627445 & 0.094417 & -6.645442 & 0.0000 \\
D(WAGE(-7)) & -0.562055 & 0.091829 & -6.120646 & 0.0000 \\
D(WAGE(-8)) & -0.548325 & 0.088229 & -6.214806 & 0.0000 \\
D(WAGE(-9)) & -0.549790 & 0.087177 & -6.306595 & 0.0000 \\
D(WAGE(-10)) & -0.701662 & 0.073473 & -9.549981 & 0.0000 \\
D(WAGE(-11)) & -0.745675 & 0.070212 & -10.62026 & 0.0000 \\
C & -1.055897 & 0.131909 & -8.004752 & 0.0000 \\
\hline \hline R-squared & 0.811093 & Mean dependent var & \\
Adjusted R-squared & 0.779165 & S.D. dependent var & & 0.006927 \\
S.E. of regression & 0.016922 & Akaike info criterion & -5.179026 \\
Sum squared resid & 0.020331 & Schwarz criterion & -4.802828 \\
Log likelihood & 230.5191 & Hannan-Quinn criter. & -5.027798 \\
F-statistic & 25.40385 & Durbin-Watson stat & \\
Prob(F-statistic) & 0.000000 & & \\
\hline \hline
\end{tabular}

\section{Conclusion}

wage $\mathrm{I}(1)$ variable.

It becomes stationary after applying the first difference. 
Date: 01/30/18 Time: 21:58

Sample (adjusted): 2010M03 2017M11

Included observations: 93 after adjustments

Trend assumption: Linear deterministic trend

Series: NPR R WAGE EURRON

Lags interval (in first differences): 1 to 2

Unrestricted Cointegration Rank Test (Trace)

\begin{tabular}{ccccc}
\hline \hline $\begin{array}{c}\text { Hypothesized } \\
\text { No. of CE(s) }\end{array}$ & Eigenvalue & $\begin{array}{c}\text { Trace } \\
\text { Statistic }\end{array}$ & $\begin{array}{c}0.05 \\
\text { Critical Value }\end{array}$ & Prob.** \\
\hline \hline None ${ }^{*}$ & 0.302503 & 60.14304 & 47.85613 & 0.0023 \\
At most 1 & 0.180943 & 26.63907 & 29.79707 & 0.1108 \\
At most 2 & 0.082868 & 8.076149 & 15.49471 & 0.4573 \\
At most 3 & 0.000336 & 0.031274 & 3.841466 & 0.8596 \\
\hline \hline
\end{tabular}

Trace test indicates 1 cointegrating eqn(s) at the 0.05 level

* denotes rejection of the hypothesis at the 0.05 level

**MacKinnon-Haug-Michelis (1999) p-values

Unrestricted Cointegration Rank Test (Maximum Eigenvalue)

\begin{tabular}{ccccc}
\hline \hline $\begin{array}{c}\text { Hypothesized } \\
\text { No. of CE(s) }\end{array}$ & Eigenvalue & $\begin{array}{c}\text { Max-Eigen } \\
\text { Statistic }\end{array}$ & $\begin{array}{c}0.05 \\
\text { Critical Value }\end{array}$ & Prob.** \\
\hline \hline None $*$ & 0.302503 & 33.50397 & 27.58434 & 0.0077 \\
At most 1 & 0.180943 & 18.56292 & 21.13162 & 0.1102 \\
At most 2 & 0.082868 & 8.044875 & 14.26460 & 0.3742 \\
At most 3 & 0.000336 & 0.031274 & 3.841466 & 0.8596 \\
\hline \hline
\end{tabular}

Max-eigenvalue test indicates 1 cointegrating eqn(s) at the 0.05 level

$*$ denotes rejection of the hypothesis at the 0.05 level

**MacKinnon-Haug-Michelis (1999) p-values

Unrestricted Cointegrating Coefficients (normalized by $b^{\prime} * \mathrm{~S} 11 * \mathrm{~b}=\mathrm{I}$ ):

\begin{tabular}{cccc}
\hline \hline NPR & $\mathrm{R}$ & WAGE & EURRON \\
0.006638 & 1.467599 & 5.744580 & 4.624589 \\
0.320881 & 0.886058 & 20.07021 & -16.29011 \\
-0.202940 & -0.413351 & -2.657529 & -4.537734 \\
0.012559 & 1.018223 & 13.29765 & 3.889345 \\
\hline \hline
\end{tabular}


Unrestricted Adjustment Coefficients (alpha):

\begin{tabular}{|c|c|c|c|c|}
\hline D(NPR) & 0.253126 & 0.029086 & 0.004572 & -0.001213 \\
\hline $\mathrm{D}(\mathrm{R})$ & -0.002061 & -0.023508 & 0.022928 & 0.000666 \\
\hline D(WAGE) & -0.005585 & -0.007473 & 0.000684 & -0.000394 \\
\hline D(EURRON) & -0.006500 & 0.009486 & 0.006931 & -0.000169 \\
\hline \multicolumn{2}{|c|}{1 Cointegrating Equation(s): } & Log likelihood & \multicolumn{2}{|l|}{414.2920} \\
\hline \multicolumn{5}{|c|}{ Normalized cointegrating coefficients (standard error in parentheses) } \\
\hline NPR & $\mathrm{R}$ & WAGE & EURRON & \\
\hline \multirow[t]{2}{*}{1.000000} & 221.1050 & 865.4647 & 696.7295 & \\
\hline & $(44.1329)$ & $(406.539)$ & $(353.969)$ & \\
\hline \multicolumn{5}{|c|}{ Adjustment coefficients (standard error in parentheses) } \\
\hline \multirow[t]{2}{*}{$\mathrm{D}(\mathrm{NPR})$} & 0.001680 & & & \\
\hline & $(0.00029)$ & & & \\
\hline \multirow[t]{2}{*}{$\mathrm{D}(\mathrm{R})$} & $-1.37 \mathrm{E}-05$ & & & \\
\hline & $(7.5 \mathrm{E}-05)$ & & & \\
\hline \multirow[t]{2}{*}{$\mathrm{D}(\mathrm{WAGE})$} & $-3.71 \mathrm{E}-05$ & & & \\
\hline & $(2.1 \mathrm{E}-05)$ & & & \\
\hline \multirow[t]{2}{*}{$\mathrm{D}(\mathrm{EURRON})$} & $-4.31 \mathrm{E}-05$ & & & \\
\hline & $(2.6 \mathrm{E}-05)$ & & & \\
\hline
\end{tabular}

2 Cointegrating Equation(s): $\quad$ Log likelihood 423.5735

\begin{tabular}{cccc}
\hline \multirow{3}{*}{$\begin{array}{c}\text { Normalized cointegrating coefficients (standard error in parentheses) } \\
\text { NPR }\end{array}$} & $\mathrm{R}$ & WAGE & EURRON \\
1.000000 & 0.000000 & 52.39285 & -60.22009 \\
& & $(8.56022)$ & $(10.4227)$ \\
0.000000 & \multirow{2}{*}{1.000000} & 3.677311 & 3.423485 \\
& & $(1.22727)$ & $(1.49430)$
\end{tabular}

Adjustment coefficients (standard error in parentheses)

$\begin{array}{ccc}\mathrm{D}(\mathrm{NPR}) & 0.011013 & 0.397259 \\ & (0.01392) & (0.07437) \\ \mathrm{D}(\mathrm{R}) & -0.007557 & -0.023855 \\ & (0.00355) & (0.01898) \\ \mathrm{D}(\mathrm{WAGE}) & -0.002435 & -0.014818 \\ & (0.00099) & (0.00530) \\ \mathrm{D}(\mathrm{EURRON}) & 0.003001 & -0.001134 \\ & (0.00120) & (0.00644)\end{array}$


3 Cointegrating Equation(s): $\quad$ Log likelihood 427.5959

$\begin{array}{cccc}\text { Normalized cointegrating coefficients (standard error in parentheses) } \\ \text { NPR } & \mathrm{R} & \text { WAGE } & \text { EURRON } \\ 1.000000 & 0.000000 & 0.000000 & 24.44469 \\ & & & (19.5389) \\ 0.000000 & 1.000000 & 0.000000 & 9.365875 \\ & & & \begin{array}{c}(1.88863) \\ 0.000000\end{array} \\ & 0.000000 & 1.000000 & -1.615960 \\ & & & (0.40005)\end{array}$

Adjustment coefficients (standard error in parentheses)

\begin{tabular}{crrr}
$\mathrm{D}(\mathrm{NPR})$ & 0.010085 & 0.395369 & 2.025707 \\
& $(0.01647)$ & $(0.07649)$ & $(0.91286)$ \\
$\mathrm{D}(\mathrm{R})$ & -0.012210 & -0.033332 & -0.544590 \\
& $(0.00409)$ & $(0.01901)$ & $(0.22691)$ \\
$\mathrm{D}(\mathrm{WAGE})$ & -0.002574 & -0.015101 & -0.183881 \\
& $(0.00117)$ & $(0.00545)$ & $(0.06504)$ \\
$\mathrm{D}(\mathrm{EURRON})$ & 0.001594 & -0.003999 & 0.134628 \\
& $(0.00140)$ & $(0.00648)$ & $(0.07737)$ \\
\hline
\end{tabular}

Dependent Variable: NPR

Method: Least Squares

Date: 01/30/18 Time: 22:02

Sample (adjusted): 2010M01 2017M11

Included observations: 95 after adjustments

\begin{tabular}{lrllr}
\hline \hline \multicolumn{1}{c}{ Variable } & Coefficient & Std. Error & t-Statistic & Prob. \\
\hline \hline \multicolumn{1}{c}{ NPR(-1) } & 0.999257 & 0.003445 & 290.0267 & 0.0000 \\
\hline \hline R-squared & 0.987025 & Mean dependent var & 15.14082 \\
Adjusted R-squared & 0.987025 & S.D. dependent var & 4.669850 \\
S.E. of regression & 0.531942 & Akaike info criterion & 1.585906 \\
Sum squared resid & 26.59846 & Schwarz criterion & 1.612789 \\
Log likelihood & -74.33054 & Hannan-Quinn criter. & 1.596769 \\
Durbin-Watson stat & 1.474961 & & \\
\hline \hline
\end{tabular}


Pairwise Granger Causality Tests

Date: 02/18/18 Time: 19:04

Sample: 2009M12 2017M11

Lags: 2

\begin{tabular}{lccc}
\hline \hline Null Hypothesis: & Obs & F-Statistic & Prob. \\
\hline \hline R does not Granger Cause EURRON & 94 & 1.74152 & 0.1812 \\
EURRON does not Granger Cause R & & 0.09086 & 0.9132 \\
\hline \hline NPR does not Granger Cause EURRON & 94 & 0.15153 & 0.8596 \\
EURRON does not Granger Cause NPR & & 3.42184 & 0.0370 \\
\hline \hline WAGE does not Granger Cause EURRON & \multirow{2}{*}{94} & 2.34375 & 0.1019 \\
EURRON does not Granger Cause WAGE & & 0.68936 & 0.5046 \\
\hline \hline NPR does not Granger Cause R & 94 & 1.36100 & 0.2617 \\
R does not Granger Cause NPR & & 20.4229 & $5 . \mathrm{E}-08$ \\
\hline \hline WAGE does not Granger Cause R & 94 & 0.06328 & 0.9387 \\
R does not Granger Cause WAGE & & 2.95856 & 0.0570 \\
\hline \hline WAGE does not Granger Cause NPR & 94 & 10.0589 & 0.0001 \\
NPR does not Granger Cause WAGE & & 0.13760 & 0.8716 \\
\hline \hline
\end{tabular}

